\title{
Organisasi Islam dan Pengarunya Pada Hukum Islam di Indonesia
}

\section{H. Muhammad Kasim}

\begin{abstract}
Abstrak
Islam merupakan agama yang universal yang mengatur semua aspek kehidupan manusia, sehingga lahirlah beberapa organisasi Islam di Indonesia seperti SI (syarikat Islam) yang berorientasi politik dengan cikal bakal dari syarikat Dagang Islam yang berorientasi bisnis yang tidak lepas dari motivasi kuat untuk mengimplementasikan ajaranajaran Islam dalam berbagai aspeknya, kemudian Muhammadiyah yang bergerak pada sosial keagamaan dan dakwah, dan Nahdatul Ulama (NU) yang sering dikatakan sebagai organisasi masa Islam tradisional yang mengembangkan ajaran empat mazhab. Dari beberapa ormas Islam yang ada di Indonesia, penulis mengambil ormas Islam yang sangat kuat pengaruhnya yaitu : N.U (Nahdatul Ulama dan Muhammadiyah), dalam pengembangan Hukum Islam di Indonesia.
\end{abstract}

\section{Pendahuluan}

Hukum Islam dan era globalisasi sering dipersepsikan dua hal yang sangat berbeda dan bahkan dikatakan saling bertentangan. Dalam satu sudut pandang, Hukum Islam merupakan sesuatu yang tidak akan mungkin mengalami perubahan, karena berdasarkan wahyu Allah.

Organisasi seringkali timbul akibat adanya tekanan. Ketidakadilan dan perlakuan diskriminasi dari pihak lain. Gerakan ini menyusun kekuatan untuk merekrut semua potensi dan menandingi kekuatan luar, sehingga eksistensinya diperhitungkan. Terlebih pada pengaruhnya pada perkembangan Hukum Islam di Indonesia pada khususnya.

Hukum selain berfungsi sebagai pengatur kehidupan masyarakat atau social control, juga berfungsi sebagai pembentuk masyarakat atau social engineering. Kedua fungsi itu diharapkan berjalan serempak, dapat menjaga dan mengatur masyarakat agar tidak terpengaruh dan menjadi korban globalisasi.

Hukum Islam bukan suatu yang statis, tetapi mempunyai daya lentur yang dapat sejalan dengan arus globalisasi yang bergerak cepat. Fleksibilitas yang dimiliki hukum Islam menyebabkan hukum Islam mampu mengikuti dan menghadapi era globalisasi karena ia telah mengalami pengembangan pemikiran melalui hasil ijtihad. Hukum Islam tanpa pengembangan akan tetap stabil dan tidak dapat menghadapi sesuatu yang bergerak. Maka diperlakukan usaha untuk

${ }^{1}$ Prof. Dr. H. Amir Syarifuddin, Meretas kebekuan Ijtihad, Isu-isu penting Hukum Islam Kontemporer di Indonesia, (Cet. II; Jakarta: PT. Ciputat Press, 2005), h. 3. 
mengembangkan hukum Islam sehingga mampu menjawab perkembangan zaman. $^{2}$

Sebagaimana diyakini bahwa Islam adalah agama universal yang mengatur semua aspek kehidupan manusia, sehingga lahirlah beberapa organisasi Islam di Indonesia seperti SI (syarikat Islam) yang berorientasi politik dengan cikal bakal dari syarikat Dagang Islam yang berorientasi bisnis yang tidak lepas dari motivasi kuat untuk mengimplementasikan ajaran-ajaran Islam dalam berbagai aspeknya, kemudian Muhammadiyah yang bergerak pada sosial keagamaan dan dakwah, dan Nahdatul Ulama (NU) yang sering dikatakan sebagai organisasi masa Islam tradisional yang mengembangkan ajaran empat mazhab.

Dari beberapa ormas Islam yang ada di Indonesia, penulis mengambil ormas Islam yang sangat kuat pengaruhnya yaitu : NU (Nahdatul Ulama dan Muhammadiyah), dalam pengembangan Hukum Islam di Indonesia. Dari latar belakang masalah yang disebutkan di atas penulis mencoba merumuskan pokok masalah mengenai sejarah berdirinya Ormas Islam NU dan Muhammadiyah serta Pengaruhnya dalam Pengembangan Hukum Islam di Indonesia.

\section{Pembahasan}

\section{Latar belakang berdirinya Nahdatul Ulama (NU) dan Muhammadiyah}

Nahdatul Ulama di dirikan pada tanggal 16 Rajab 1344 H (31 Januari 1926) ${ }^{3}$ di Surabaya. Pendirinya adalah alim ulama dari tiap-tiap daerah di Jawa Timur salah satunya adalah KH. Hasyim Asy'ari. Didirikan organisasi tersebut di latarbelakangi oleh dua tujuan :

1. Untuk mengimbangi Komite Khilafat yang secara berangsur-angsur jatuh ke tangan golongan pembaharuan.

2. Untuk berseru kepada Ibnu Suud, penguasa baru di tanah Arab agar kebiasaan beragama secara tradisi dapat diteruskan. ${ }^{4}$

Dilihat dari sejak berdirinya sampai sekarang cukup memberikan suatu pemahaman kepada kita bahwa NU sebagai organisasi keagamaan ini benar-benar sangat menginginkan adanya satu gerak kebersamaan dalam komunitas masyarakat Muslim dengan berada pada satu gerak komando untuk mewujudkan tujuan bersama. Dan pada masa itu juga NU merupakan sebuah organisasi yang diatur oleh sejumlah ulama dan aktivis yang mempunyai kharisma, kekuatannya tampak lebih tertumpu pada pengaruhnya terhadap ummat dan ulama di tingkat yang lebih rendah ketimbang pada pengorganisasian yang rapi.

Sekalipun NU mempertahankan ortodoksi scholastic abad pertengahan namun dalam konteks membangkitkan semangat umat Islam, gerakan ini berhasil

\footnotetext{
${ }^{2}$ Ibid., h. 3-4.

${ }^{3}$ Prof. Dr. Faisal Ismail, M.A., Dileman NU, Ditengah Badai Pragmatisme Politik, (Cet. I; Jakarta: Proyek Peningkatan Kehidupan Beragama Badan Litbang Agama dan Diklat Keagamaan Depag RI, 2004), h. 10-11.

${ }^{4}$ M. Din Syamsudin, Muhammadiyah Kiri dan Dan Esok, (Jakarta: pustaka Panjimas, 1990), h. 42
} 
melalui lembaga-lembaga pondok pesantren, NU berhasil menanamkan semangat dan watak anti kolonialisme dengan berpegang teguh pada ajaran Islam dan memelihara semangat ahlus Sunnah wal jamaah, NU berhasil menggalang persatuan dan kekuatan umat Islam. ${ }^{5}$

Sedangkan lahirnya Muhammadiyah, pada tanggal 8 Zulhijjah 1330 (18 Nopember 1912) di Yogyakarta ${ }^{6}$, dan sejarah hidup pendiri awalnya yakni KH. Ahmad Dahlan, karma dari pemikiran dan usaha beliaulah lahirnya embrio organisasi yang kemudian setelah mengalami perputaran waktu berubah menjadi seperti dan sebesar sekarang ini.

KH. Ahmad Dahlan dilahirkan di Yogyakarta pada tahun 1869 dengan nama kecilnya adalah Muhammad Darwis ${ }^{7}$ anak dari KH Abubakar bin Kiyai Sulaiman, khatib di Masjid sultan di kota itu, ibunya adalah anak dari Haji Ibrahim penghulu. Seteleh ia menyelesaikan pendidikan dasarnya dalam ilmu nahu, fiqhi dan tafsir di Yogya dan sekitarnya, ia pergi ke Mekkah ( tahun 1890) dan belajar kepada Syaikh Ahmad Khatib yang merupakan salah saorang dari guru-guru beliau selama di kota Mekkah, dan sekitar tahun 1903 ia kembali mengunjungi Indonesia.

Dalam tahun 1909 Ahmad Dahlan masuk organisasi Budi Utomo dengan maksud memberikan pelajaran agama kepada anggota-anggotanya, dengan jalan ini ia berharap dapat memberikan pelajaran agama di sekolah-sekolah pemerintah, karena anggota-anggota budi Utomo pada umumnya bekerja di sekolah-sekolah pemerintah. $^{8}$

Ada beberapa alasan yang dikemukakan oleh kalangan Muhammadiyah yang menjadi faktor didirikannya organisasi ini Oleh KH. Ahmad Dahlan antara lain : ${ }^{9}$

1. Ia melihat bahwa umat Islam tidak memegang teguh al-Qur'an dan Sunnah dalam beramal sehingga takhayul dan syirik merajalela, ahlak masyarakat runtuh. Akibatnya, amalan-amalan mereka merupakan campuran antara yang benar dan salah. Sebagaimana diketahui, orang-orang Indonesia sudah beragama Hindu sebelum datangnya Islam. Menurut catatan sejarah, agama Hindu dibawah pertama kali masuk Indonesia oleh pedagang-pedagang India sehingga pengaruhnya tidak terlepas dari umat Islam.

2. Lembaga-lembaga pendidikan agama yang ada pada waktu itu tidak efisien. Pesantren, yang menjadi lembaga pendidikan kalangan bawah, pada masa itu dinilai tidak sesuai lagi dengan perkembangan kebutuhan masyarakat. Pada waktu itu pendidikan di Indonesia telah

\footnotetext{
${ }^{5}$ H. Alamsyah Ratu Perwiranegara, Islam dan Pembangunan Politik di Indonesia, (Jakarta; cv. Haji Mas Agung, 1987), h. 186-187.

${ }^{6}$ Ensiklopedi Islam, Jilid III (Cet. III; Jakarta : PT. Ichtiar Baru Van Hoeve, 1994), h. 275.

${ }^{7}$ Semula ia bernama Muhammad Darwis, dan salah seorang gurunya yang bernama Sayyid Bakri Syatha' yang menjabat sebagai mufti atau imam dari mazhab syafi'I di Mekkah, beliau kemudian diberi nama baru yaitu : Ahmad Dahlan, sedangkan gelar Kyai didapat setelah pulang ke Kauman Yogyakarta dan mengajar di sana, Lihat MT Arifin, Gagasan Pembaruan Muhammadiyah (Pustaka Jaya, Bandung, 1987), h. 79.

${ }^{8}$ Deliar Noer, Gerakan Modern Islam di Indonesia 1900-1942 (LP3ES; Jakarta), h. 86

${ }^{9}$ Ensiklopedi Islam, Jilid III, loc.cit.
} 
terpecah dua, yaitu pendidikan secular yang dikembangkan oleh Belanda dan pedidikan pesantren yang hanya mengajarkan ilmu-ilmu yang berhubungan dengan agama. Akibatnya terjadi jurang pemisah yang sangat dalam antara golongan yang mendapat pendidikan secular dan golongan yang mendapatkan pendidikan di pesantren. Ini juga mengakibatkan terpecah rasa persaudaraan (Ukhuwah Islamiyah) di kalangan umat Islam dan semakin melemahnya kekuatan umat Islam.

3. Kemiskinan menimpa rakyat Indonesia, terutama umat Islam, yang sebagian besar adalah petani dana buruh. Orang kaya hanya mementingkan dirinya sendiri, dan bahkan banyak ulama lupa mengingatkan umatnya bahwa Islam mewajibkan zakat bagi si kaya, sehingga hak-hak orang miskin terabaikan.

4. Aktivitas misi Katolik dan Protestan sudah giat beroperasi sejak awal abad ke-19 dan bahkan sekolah-sekolah misi mendapat subsidi dari pemerintah Hindia Belanda.

5. Kebanyakan umat Islam hidup dalam alam fanatisme yang sempit, bertaklid buta, serta berpikir secara dogmatis. Kehidupan umat Islam masih diwarnai konservatisme, formalisme, dan tradisionalisme.

Mulanya daerah operasional Muhammadiyah sangat terbatas, hanya di Kauman Yogyakarta saja. Setelah kongres Budi Utomo (1917) dimana Ahmad Dahlan menyampaikan pidatonya yang sangat memukau peserta kongres, sehingga pengurus Muhammadiyah menerima permintaan dari berbagai tempat untuk mendirikan cabang-cabangnya, untuk maksud tersebut anggaran dasarnya yang membatasi pada kegiatan-kegiatan di Yogyakarta saja, haruslah terlebih dahulu dirobah, maka pada tahun 1920 daerah kegiatan Muhammadiyah diluaskan meliputi seluruh pulau Jawa dan pada tahun 1921 ke seluruh Indonesia. ${ }^{10}$

Organisasi wanitanya bernama Aisyiyah, semula merupakan suatu organisasi yang terdiri dari kaum wanita di Yogyakarta yang berdiri pada tahun 1918 dengan nama Sopotrisno, kemudian tahun 1922 organisasi ini resmi menjadi bagian dari Muhammadiyah, kemudian disusul dengan berdirinya Hizbul Wathan dan majelis-majelis lainnya. ${ }^{11}$

Organisasi Muhammadiyah senantiasa terpanggil untuk berkiprah dalam kehidupan berbangsa dan bernegara dengan berlandaskan pada 9 khittah perjuangan diantaranya adalah : Muhammadiyah meminta kepada segenap anggotanya yang aktif dalam politik untuk benar-benar melaksanakan tugas dan kegiatan politik secara bersungguh-sungguh dengan mengedepankan tanggung jawab (al-Amanah), akhlak mulia (al-Akhlak al-Karimah), keteladanan (alUswah al-Hasanah), dan perdamaian (al-Islah). Dan segala aktifitasnya harus sejalan dengan upaya memperjuangkan amar ma'ruf nahi mungkar. ${ }^{12}$

\footnotetext{
${ }^{10}$ Ibid, h. 87

${ }^{11}$ Ibid.

${ }^{12}$ Hajriyanto Y Thohari, Muhammadiyah dan pergulatan Politik Islam Modernis, (Cet. I; Jakarta: PSAP Muhammadiyah, 2005), h. xvii.
} 


\section{Pengaruhnya dalam Pengembangan Hukum Islam di Indonesia}

Syari'at atau Syari'at Islam adalah bagian dari Agama. Agama bagi umat Islam mengandung dua sisi. (Pertama) Apa yang harus diyakininya; (Kedua) Apa yang harus diamalkannya.

Ketentuan tentang apa yang harus diyakininya disebut dengan akidah, Petunjuk tentang apa yang harus diamalkannya disebut syari'at. Dan Mahmud Syaltut memandang dan menempatkan Islam sebagai akidah dan syari'ah, dikarenakan bahwa Allah swt menetapkan syari'at adalah untuk kemaslahatan manusia, dengan memenuhi kebutuhan-kebutuhan pokoknya (daruriyat, hajiyat, tahsiniyat).

Sedangkan Hukum Islam sejak kedatangannya di bumi Nusantara Indonesia hingga pada hari ini tergolong hukum yang hidup (living law) di dalam masyarakat. Bukan saja karena hukum Islam merupakan entitas agama yang dianut oleh mayoritas penduduk hingga saat ini, akan tetapi dalam dimensi amaliahnya dibeberapa daerah ia telah menjadi bagian tradisi (adat) masyarakat yang terkadang dianggap sakral.

Di Indonesia, pelaksanaan hukum Islam diwakili oleh beberapa institusi, MUI lebih dikenal oleh masyarakat sebagai lembaga yang berusaha menyelesaikan banyak permasalahan agama dengan mengeluarkan fatwa, KUA bertugas melakukan pencatatan perkawinan dan wakaf; Peradilan Agama bertugas menangani masalah hukum al-ahwal al-syakshiyyat (hukum keluarga muslim) yang terjadi di masyarakat. Produk Peradilan adalah ketetapan (ishbat) dan keputusan yang fiqh disebut al-qadha'. Disamping itu, ormas-ormas Islam seperti Muhammadiyah dan Nahdatul Ulama (NU) juga beberapa ormas Islam lainnya memiliki institusi yang bertugas untuk mendalami dan merekomendasikan pendapat (bahkan sikap) organisasi terhadap persoalan (hukum) yang terjadi di masyarakat. ${ }^{13}$

Dari persoalan-persoalan yang terjadi dimasyarakat tidak terlepas dengan pengaruh modernisasi, begitu pula dengan pengambilan beberapa keputusan yang dikeluarkan oleh ormas-ormas Islam tidak terlepas dengan pengaruh mazhabmazhab yang berkembang di Asia Tenggara.

Dalam masyarakat muslim Asia Tenggara misalnya perkembangan mazhab syafi'i. mazhab ini dapat tersebar luas di Asia Tenggara melalui aktifitas para tokoh dan ulamanya melalaui beberapa cara, yang terpenting di antaranya melalui lembaga pengajian fiqh dan ushul fiqh. ${ }^{14}$

Dalam Q.S. al-Taubah ayat 122 menjelaskan bahwa ada dua kelompok dalam setiap golongan umat sehubungan dengan tugas memahami ajaran agama dan pengamalannya. Pertama, merupakan bagian kecil dari golongan kaum yang bertugas mendalami agama (tafaqqah fi al-dien), setelah mereka berhasil dalam usahanya, mereka bertugas pula menyampaikan dan mengajarkan pengetahuannya kepada kaumnya. Kedua, golongan yang terbesar dari kaum yang tidak ikut

\footnotetext{
${ }^{13}$ Mubarak Jaih, Metodologi Ijtihad Hukum Islam, (Yogyakarta: UII Press, 2002), h. 168.

${ }^{14}$ Amir Syarifuddin, op.cit, h. 101.
} 
mendalami agama. Oleh karena dalam bidang agama mereka menerima pengajran dari kelompok pertama. ${ }^{15}$

Kelompok pertama disebut mujtahid, Sedangkan kelompok kedua yang merupakan kelompok umum disebut golongan "awam" golongan awam dalam mengamalkan agama karena tidak mempunyai pengetahuan, dianjurkan bertanya kepada orang yang tahu. Hal tersebut dijelaskan Allah dalam Q.S. an-Nahl : 42 yang terjemahannya "Dan Kami tidak mengutus sebelum kamu, kecuali orangorang lelaki yang Kami beri wahyu kepada mereka; Maka bertanyalah kepada orang yang mempunyai pengetahuan, jika kamu tidak mengetahui."

Di sini penulis mengartikan bahwa golongan mujthid adalah satu kelompok yang memahami dan mendalami pengatahuan tentang agama (ormas Islam), dan kedua adalah kelompok masyarakat awam yang kurang pengetahuannya.

Seperti yang penulis mencoba mengangkat kembali kasus ajinomoto yang terjadi pada akhir Nopember 2000 yang diketahui bahwa dalam proses produksinya menggunakan bahan penolong berupa bacro soytone yang mengandung unsur enzim babi, seperti yang difirman Allah dalam Q.S. alBaqarah (2): 173, tentang pengharaman memakan babi.

Temuan tersebut diperoleh Lembaga Pengkajian Pangan, Obat-obatan, dan kosmetika Majelis Ulama Indonesia (LP-POM MUI) setelah melakukan pemeriksaan terhadap produk tersebut yang kemudian ditindaklanjuti dengan kunjungan (audit) anggota komisi fatwa ke perusahaan PT. Ajinomoto pada tanggal 4 Desember 2000. ${ }^{16}$

Dari kunjungan anggota komisi fatwa MUI ke perusahaan PT. Ajinomoto tersebut menyatakan bahwa "dalam proses pembuatan MSG dari PT. Ajinomoto terjadi percampuran (pertemuan, persenyawaan, الختلاط ) medium agar-agar, baktyeri, dan bacto soytone (yang mengandung enzim babi) dalam satu tempat/ wadah, dan sama-sama basah, untuk mengembangbiakkan bakteri yang digunakan dalam proses selanjutnya untuk menghasilkan MSG" 17

Dari kasus tersebut, maka pengambilan keputusan (fatwa MUI) maupun ormas Islam lainnya (khususnya Muhammadiyah dan Nahdatul Ulama) tidak terlepas dari metode-metode Ijtihad yang digunakan seperti yang digunakan oleh NU, bahwa secara garis besar metode pengambilan keputusan hukum yang ditetapkan oleh NU dibedakan menjadi dua bagian yaitu :

1. Ketentuan hukum;

2. System pengambilan keputusan hukum serta Petunjuk pelaksanaannya. ${ }^{18}$

Dalam Ketentuan umum dijelaskan mengenai al-kutub al-mu'tabarat (kitab standart). Dalam keputusan tersebut tidak terdapat rincian mengenai kitab standard. Akan tetapi, ia direferensikan kepada rumusan Muktamar NU ke-27.

${ }^{15}$ Ibid.

${ }^{16}$ Ibid, h, 171-172.

${ }^{17}$ Ibid, h. 173.

18 K.H.A. Aziz Masyumi, Masalah Keagamaan : Hasil Muktamar dan Munas Ulama Nahdatul Ulama kesatu-1926 s.d kedua puluh sembilan-1994, (Surabaya: PP-RMI dan Dinamika Press, 1977), h. 364-367. 
akan tetapi, dalam keputusan tersebut dikatakan bahwa yang dimaksud dengan alkutub al-mu'tabarat adalah kitab-kitab yang sesuai dengan akidah ahl al-Sunnat wa al-Jama'at. Dan penjelasan berikutnya merupakan rumusan mengenai caracara bermazhab atau mengikuti aliran hukum (fiqh) dan akidah (keyakinan) tertentu. Aliran fiqh dapat diikuti dengan dua cara : pertama, bermazhab secara qawli, yaitu mengikuti pendapat-pendapat yang sudah jadi dalam lingkup aliran atau mazhab tertentu; dan kedua bermazhab secara manhaji, yaitu bermazhab dengan mengikuti jalan pikiran dan kaidah penetapan hukum yang telah disusun oleh imam mazhab.

Sedangkan pengambilan hukum di lingkungan Nahdatul Ulama adalah system pengambilan keputusan hukum. Dari system pengambilan keputusan hukum dikatakan bahwa keputusan baths al-masa'il dibuat dalam bermazhab kepada salah satu dari empat mazhab yang disepakati dan mengutamakan bermazhab secara qawli.

Pedoman MT-PPI ${ }^{19}$ (Majlis Tarjih dan Pengembangan Pemikiran Islam) Muhammdiyah, secara umum dapat dikelompkkan menjadi dua yaitu :

1. Manhaj Ijtihad hukum dan,

2. Manhaj pengembangan pemikiran Islam.

Bagi Muhammadiyah, sumber hukum adalah al-Qur'an dan al-Sunnah, Sedangkan ruang lingkup Ijtihad bagi Muhammadiyah adalah : ${ }^{20}$

a. Masalah-masalah yang terdapat dalam dalil zhanniy;

b. Masalah-maslah yang secara eksplisit tidak terdapat dalam al-qur'an dan as-Sunnah.

MT-PPI membedakan tiga istilah teknis dalam Ijtihad, yaitu metode, pendekatan dan teknik. Metode Ijtihad MT-PPI adalah : ${ }^{21}$

a. Bayani (semantic) yang metode istinbath hukum dengan pendektan kebahasaan;

b. Ta'lili (rasional) yaitu metode istinbath hukum dengan pendetakan berfikir logis (nalar); dan

c. Istishlahi (filosofis), yaitu metode istinbath hukum dengan pendekatan kemashlahatan.

Dan pendekatan MT-PPI dalam berijtihad adalah pendekatan :

a. Sejarah

b. Sosiologi

c. Antropologi,

d. Hermenautik

${ }^{19}$ Mengurangi Perbedaan pendapat dengan jalan Musyawarah dan kembali kepada alQuran dan as-Sunnah; (b) relativitas keputusan MT-PPI. Dengan dua prinsip ini, pengurangan perbedaan pendapat dan ketidakabsolutan keputusan MT-PPI, Muhammdiyah berharap bahwa pemikiran keagamaan di masyarakat terus berkembangan kea rah yang lebih baik. Sedangkan rujukan MT-PPI adalah al-qura'n dan as-Sunnah, lihat Mau'ammal Hamidy, Manhaj Tarjih dan perkembangan pemikiran ke-Islaman dan Muhammdiyah dalam Muhammad Azhar dan Hamim ilyas (ed), Pengembangan pemikiran ke-Islaman Muhammadiyah: Purifikasi dan Dinamisasi, (Yogyakarta: LPPI UMY, 2000), h. 22.

${ }^{20}$ Jain Mubarak, op, cit, h. 176.

${ }^{21}$ Lebih jelasnya lihat, Ibid, h. 176-177. 
Sedangkan Ijtihad MT-PPI adalah :
a. Ijmak
b. Qiyas
c. Mashlah mursalat, dan
d. Al-'Urf

Jika menilik persoalan stagnasi gerakan Muhammadiyah dalam konteks pemikiran (Islam), sebenarnya ada dua faktor fundamental yang perlu kita cermati bersama. Pertama : tentang tarik ulur ideologi kanan (fundamental, liberal). Hal ini bukan maslah yang sepele, karena peta pemikiran dari para tokoh yang menduduki posisi di pimpinan pusat Muhammadiyah telah terbelah dalam dua kelompok yang kontras sama sekali, yaitu antara kubu yang berhaluan literalnormatif, dan terkadang agak fundamentalis, serta kubu yang berhaluan liberal dan Kritis. Kedua kubu itu saling konfrontatif, sehingga menimbulkan suasana yang kurang sehat, karena masing-masing sepertinya kurang mengedepankan sikap inklusif dalam menanggapi setiap pemikiran yang bergulir. ${ }^{22}$ Kedua : masalah stagnasi pemikiran di Majelis Tarjih dan pengembangan Muhammadiyah ke-42 di banda Aceh tahun 1955, nama Majelis Tarjih mendapat tambahan "Pengembangan Pemikiran Islam" sehingga jelas menambah tugas ddan fungsinya. Jika sebelumnya Majelis Tarjih hanya sebatas memberikan fatwafatwa yang terhimpun dalam Himpunan Putusan Tarjih (HPT), maka pasca Muktamar ke-42 itu mendapat tanggung jawab untuk menggarap wacana-wacana ke-Islaman Kontemporer. ${ }^{23}$

Melihat fenomena seperti itu, di satu sisi, sebenarnya bisa dikatakan wajar, karena sebagai organisasi yang usianya jauh lebih tua dari RI, Muhammadiyan telah matang dari segi birokrasi. Bukan hanya itu, segala amal usaha Muhammadiyah mulai dari bidang pendidikan (TK, sampai Perguran Tinggi), Kesehatan (PKU/Rumah sakit Muhammadiyah), ekonomi dan lain sebagainya telah menjadikan persyarikatan ini semakin gemuk. Namun, Akibatnya banyak amal usaha yang harus diurusi, warga Muhammadiyah malah disibukkan dengan urusan keduniawian mereka. Hal ini jelas berdampak pada kelambanan perkembangan pemikiran di Muhammadiyah. Menganai hal ini, ada sebuah sindiran yang cukup tanda dilontarkan oleh Prof. Dr. Yunan Yusuf ( Ketua Majelis Dikdasmen Pimpinan Pusat Muhammadiyah), ----Muhammadiyah sekarang ibarat gajah yang gemuk. Geraknya sudah tidak lagi segesit dahulu." 24

Dengan demikian pengembangan pemikiran serta pengaruh ormas Islam dalam pengembangan hukum Islam di Indonesia sangatlah berpengaruh dikarenakan kondisi masyarakat Islam di Indonesia yang mempunyai corak ragam budaya yang berbeda-beda, sehingga permasalahan-permasalahan yang timbul sebelum pada masyarakat sekarang ini tidaklah terdapat pada zaman Islam di zaman Nabi Muhammad saw. Sehingga setiap pengambilan keputusan hukum yang terjadi selalu melihat latar belakang serta kondisi yang dialami oleh seseorang dengan tidak meninggalkan Qur'an dan Sunnah sebagai Pedoman.

\footnotetext{
${ }^{22}$ Mu'arif, Meruwat Muhammadiyah kritik seabad Pembaruan Islam di Indonesia (Cet. I; Yogyakarta: Pilar Religia_Kelompok Pilar Media, 2005), h. 4-5.

${ }^{23}$ Ibid., h. 7.

${ }^{24}$ Ibid., h. 60-61.
} 
Kemudian jika dijelaskan bahwa hukum syara' itu adalah titah Allah yang bernilai hukum dan jumlahnya sangat sedikit bila dibandingkan dengan keseluruhan titah Allah yang terdapat dalam al-Qur'an.

Jika titah Allah bernilai hukum itu hanya mengatur apa yang tersebut sebagaimana dalam teks suci maka sangat sedikit yang terjangkau oleh aturan Allah, padahal yang harus tunduk kepada aturan Allah sangat kompleks permasalahannya. Oleh karena itu diperlukan usaha pengembangan hukum Islam dengan arti titah allah bernilai hukum, dapat diperlakukan untuk maksud yang lebih baik. Namun bila ditinjau sebagai aturan dasar yang memerlukan pemahaman dalam pelaksanaannya, maka pemahaman titah Allah tersebut dapat mengalami perubahan dan pengembangan. Pengembangan Hukum Islam dapat diartikan sebagai perentangan (perluasan) maksud Allah dalam titahnya itu kepada maksud lain, sehingga penggunaannya menjadi semakin luas. Pengembangan dalam arti perentangan ini mengandung dua cara pertama perentangan lafadz dengan semata menggunakan pemahaman lughawi, dan kedua, adalah perentangan lafadz kepada sasaran lain tidak semacan menggunakan pemahaman lughawi, tapi dengan cara memahami illat dan alasan Allah dalam menetapkan hukumnya.

Kita yakin bahwa para Ulama khususnya ulama NU dan Ulama Muhammadiyah, akan berhasil melakukan revitalisasi posisi dan peranan mereka dalam membentengi umat dan bangsa ini dengan keteladanan moral yang baik, mulia dan luhur yang bertumpu pada ajaran amar ma'ruf nahi mungkar, dan kita berharap bahwa bangsa ini bisa beratahan (survive) dan tidak akan ambruk (collapse) karena telah dibentengi dengan basisi kekuatan spiritual dan keteladanan moral yang baik, mulia dan luhur oleh para ulama pada umumnya dan ulama NU serta ulama Muhammadiyah khususnya.

\section{Penutup}

Sebagai akhir dari makalah ini, penulis mencoba menyimpulkan pengaruh ormas Islam dalam pengembangan Hukum Islam di Indonesia, yaitu :

1. bahwa pengembangan Hukum Islam di Indonesia tidak terlepas dari pengaruhnya para ulama di Indonesia khususnya ulama-ulama dari golongan NU dan golongan Muhammadiyah.

2. Dalam kehidupan bermasyarakat terdapat dua kelompok yang pertama adalah: merupakan bagian kecil dari golongan kaum yang bertugas mendalami agama (tafaqqah $f i$ al-dien), setelah mereka berhasil dalam usahanya, mereka bertugas pula menyampaikan dan mengajarkan pengetahuannya kepada kaumnya, Sedangkan yang kedua adalah : golongan yang terbesar dari kaum yang tidak ikut mendalami agama. Oleh karena dalam bidang agama mereka menerima pengajran dari kelompok pertama.

3. Dari setiap ormas Islam yang terdapat di Indonesia mempunyai cara-cara tersendiri dalam pengembangan Hukum Islam itu tersendiri dan selalu berdasarkan kepada al-Qur'an dan Sunnah serta Qias dan Ijma, sebagai rujukan pertama dalam setiap pengambilan (mengistinbathkan) suatu hukum 
dalam penyelesaian masalah-masalah yang terjadi dalam masyarakat itu sendiri.

\section{Daftar Pustaka}

Prof. Dr. H. Amir Syarifuddin, Meretas kebekuan Ijtihad, Isu-isu penting Hukum Islam Kontemporer di Indonesia (Cet. II; Jakarta: PT. Ciputat Press, 2005).

M. Din Syamsudin, Muhammadiyah Kiri dan Dan Esok (Jakarta: Pustaka Panjimas, 1990).

H. Alamsyah Ratu Perwiranegara, Islam dan Pembangunan Politik di Indonesia (Jakarta; CV. Haji Mas Agung, 1987).

MT Arifin, Gagasan Pembaruan Muhammadiyah (Bandung: Pustaka Jaya, 1987).

Deliar Noer, Gerakan Modern Islam di Indonesia 1900-1942 (Jakarta: LP3ES).

Mubarak Jaih, Metodologi Ijtihad Hukum Islam (Yogyakarta: UII Press, 2002).

Mau'ammal Hamidy, Manhaj Tarjih dan perkembangan pemikiran ke-Islaman dan Muhammdiyah dalam Muhammad Azhar dan Hamim ilyas (ed), Pengembangan pemikiran ke-Islaman Muhammadiyah: Purifikasi dan Dinamisasi (Yogyakarta: LPPI UMY, 2000).

Hajriyanto Y Thohari, Muhammadiyah dan pergulatan Politik Islam Modernis (Cet. I; Jakarta: PSAP Muhammadiyah, 2005).

Prof. Dr. Faisal Ismail, M.A., Dileman NU, Ditengah Badai Pragmatisme Politik (Cet. I; Jakarta: Proyek Peningkatan Kehidupan Beragama Badan Litbang Agama dan Diklat Keagamaan Depag RI, 2004).

Ensiklopedi Islam, Jilid III (Cet. III; Jakarta : PT. Ichtiar Baru Van Hoeve, 1994).

Mu'arif, Meruwat Muhammadivah kritik seabad Pembaruan Islam di Indonesia. 